University of Nebraska - Lincoln

DigitalCommons@University of Nebraska - Lincoln

USDA National Wildlife Research Center - Staff Publications
U.S. Department of Agriculture: Animal and Plant Health Inspection Service

February 2007

\title{
Influence of land use and climate on wetland breeding birds in the Prairie Pothole region of Canada
}

\author{
G. M. Forcey \\ North Dakota State University \\ G. M. Linz \\ USDA/APHIS/WS National Wildlife Research Center, george_m_linz@yahoo.com
}

W. E. Thogmartin

US Geological Survey, Upper Midwest Environmental Sciences Center

W. J. Bleier

North Dakota State University

Follow this and additional works at: https://digitalcommons.unl.edu/icwdm_usdanwrc

Part of the Environmental Sciences Commons

Forcey, G. M.; Linz, G. M.; Thogmartin, W. E.; and Bleier, W. J., "Influence of land use and climate on wetland breeding birds in the Prairie Pothole region of Canada" (2007). USDA National Wildlife Research Center - Staff Publications. 709.

https://digitalcommons.unl.edu/icwdm_usdanwrc/709

This Article is brought to you for free and open access by the U.S. Department of Agriculture: Animal and Plant Health Inspection Service at DigitalCommons@University of Nebraska - Lincoln. It has been accepted for inclusion in USDA National Wildlife Research Center - Staff Publications by an authorized administrator of DigitalCommons@University of Nebraska - Lincoln. 


\title{
Influence of land use and climate on wetland breeding birds in the Prairie Pothole region of Canada
}

\author{
G.M. Forcey, G.M. Linz, W.E. Thogmartin, and W.J. Bleier
}

\begin{abstract}
Bird populations are influenced by a variety of factors at both small and large scales that range from the presence of suitable nesting habitat, predators, and food supplies to climate conditions and land-use patterns. We evaluated the influences of regional climate and land-use variables on wetland breeding birds in the Canada section of Bird Conservation Region 11 (CA-BCR11), the Prairie Potholes. We used bird abundance data from the North American Breeding Bird Survey, land-use data from the Prairie Farm Rehabilitation Administration, and weather data from the National Climatic Data and Information Archive to model effects of regional environmental variables on bird abundance. Models were constructed a priori using information from published habitat associations in the literature, and fitting was performed with WinBUGS using Markov chain Monte Carlo techniques. Both land-use and climate variables contributed to predicting bird abundance in CA-BCR11, although climate predictors contributed the most to improving model fit. Examination of regional effects of climate and land use on wetland birds in CA-BCR11 revealed relationships with environmental covariates that are often overlooked by small-scale habitat studies. Results from these studies can be used to improve conservation and management planning for regional populations of avifauna.
\end{abstract}

Résumé : Les populations d'oiseaux sont influencées par une foule de facteurs, tant à petite qu'à grande échelle, qui vont de la présence d'un habitat adéquat de nidification, de prédateurs et de ressources alimentaires jusqu'aux conditions climatiques et aux patrons d'utilisation des terres. Nous évaluons les influences des variables du climat et de l'utilisation régionale des terres sur la reproduction d'oiseaux nichant dans les terres humides dans la région 11 de protection des oiseaux au Canada (CA-BCR11), soit les mares des prairies. Nous utilisons les données d'abondance des oiseaux de l'Inventaire nordaméricain des oiseaux nicheurs, les données d'utilisation des terres de l'Administration du rétablissement agricole des prairies et les données climatiques des Archives nationales d'information et de données climatologiques pour élaborer un modèle des effets des variables environnementales régionales sur l'abondance des oiseaux. Nous avons construit des modèles a priori à partir de données sur les associations d'habitat dans la littérature et nous les avons ajustés à l'aide du logiciel WinBUGS avec des techniques de Monte Carlo par chaînes de Markov. Tant les variables du climat que de l'utilisation des terres contribuent à la prédiction de l'abondance des oiseaux dans la région CA-BCR11, bien que ce soient les variables climatiques explicatives qui contribuent le plus à l'amélioration de l'ajustement du modèle. L'examen des effets régionaux du climat et de l'utilisation des terres dans la région CA-BCR 11 montre des relations avec les covariables environnementales qui sont souvent ignorées dans les études d'habitat à petite échelle. Les résultats de nos études peuvent servir à améliorer la planification en vue de la conservation et l'aménagement des populations régionales de la faune aviaire.

[Traduit par la Rédaction]

\section{Introduction}

Environmental factors can influence bird populations at a variety of different spatial scales. Small-scale habitat studies that focus on microhabitats (e.g., Clark and Weatherhead 1986; Murkin et al. 1997; Vierling 1999) have been the primary focus for biologists conducting avian habitat studies. While these investigations provide important data on small- scale habitat associations, they often overlook influences that are present at larger scales.

Although results from local habitat studies are important, researchers have become interested in conducting habitat analyses at larger scales because planning for conservation is occurring at regional, national, and continental levels. The number of habitat studies at larger scales is growing as a result of the wide availability of readily accessible spatial

Received 11 August 2006. Accepted 23 January 2007. Published on the NRC Research Press Web site at http://cjz.nrc.ca on 30 March 2007.

G.M. Forcey ${ }^{\mathbf{1}, \mathbf{2}}$ and W.J. Bleier. Department of Biological Sciences, North Dakota State University, Fargo, ND 58105, USA.

G.M. Linz. US Department of Agriculture, Wildlife Services, National Wildlife Research Center, 2110 Miriam Circle, Bismarck, ND 58501, USA.

W.E. Thogmartin. US Geological Survey, Upper Midwest Environmental Sciences Center, 2630 Fanta Reed Road, La Crosse, WI 54603, USA.

${ }^{1}$ Corresponding author (e-mail: research(a) gregforcey.com).

${ }^{2}$ Present address: Pandion Systems, 4603 NW 6th Street, Gainesville, FL 32609, USA. 
data via the Internet, powerful geographic information system (GIS) software, and increased computer processing speed. Additionally, large-scale data sets such as the North American Breeding Bird Survey (NABBS) (Sauer et al. 2005), the generalized land cover for the Canadian Prairies (Ashton 2001), and climate data from the National Climate Data and Information Archive (Environment Canada 2002) are freely available to those with Internet access. Modern personal computers, in conjunction with powerful GIS software, have made complex analyses at larger scales feasible (Greenberg et al. 2002). These technologies have allowed scientists to collect and analyze data across broad geographic areas, permitting habitat-related studies at corresponding scales. The use of Bayesian approaches to create population models also has recently become feasible because of increases in computer speed (Link and Sauer 2002; Calder et al. 2003; Thogmartin et al. 2004b). Bayesian approaches can accommodate nuisance effects that are often present in large-scale data sets. Nuisance effects can include overdispersion in count data, observer and year effects associated with data collection, and spatial autocorrelation (Thogmartin et al. 2004b).

Avian communities are highly influenced by habitat patterns in the landscape. Bird distributions and occurrence can be most heavily influenced by landscape habitat patterns, specifically habitat features within the landscape matrix (Saab 1999). Landscape features are particularly important to Neotropical bird migrants. Landscapes with greater percentages of natural habitats can have positive effects on Neotropical bird abundance, whereas increased landscape diversity and edge can have negative effects on abundance (Flather and Sauer 1996). Landscape-level habitat variables are also important influences on wetland breeding bird abundance and distribution. Fairbairn and Dinsmore (2001) found landscape habitat variables to be important predictors of bird abundance for seven total waterfowl and passerine species. Additionally, total grassland area and total wetland area have been shown to be important predictors of wetland bird occurrence (Naugle et al. 2000, 2001). Mallard (Anas platyrhynchos L., 1758) abundance is also affected by landscape influences, with abundance being positively related to areas of wetlands and rice and negatively related to areas of orchards and urban lands (Newbold and Eadie 2004).

Environmental factors can have different effects on birds, depending on the scale of the analysis. Red-winged blackbirds (Agelaius phoeniceus (L., 1766)) use cattail density immediately around the nest for selecting nest sites, while ignoring this factor at broader scales (Pribil and Picman 1997). Saab (1999) found landscape features to be most important when evaluating bird-habitat relationships at the landscape, microhabitat, and macrohabitat scales. Thogmartin et al. $(2004 b, 2006)$ noted landscape factors differed in their influence on cerulean warblers (Dendroica cerulea (Wilson, 1810)) and grassland birds at varying scales. The importance of scale in landscape analyses necessitates the examination of habitat influences at multiple scales so that important relationships are not overlooked (Urban 2005).

While landscape-level habitat studies have become increasingly common, more recent research has begun to examine environmental influences at larger extents, including multiple states or provinces. Because political boundaries are not ecologically meaningful, biologists often evaluate multistate bird-environment relationships within one or more Bird Conservation Regions (BCRs) across political boundaries. BCRs are ecologically unique areas with similar avian communities and are used to foster a large-scale approach to bird conservation and management (North American Bird Conservation Initiative 2005). BCRs have been shown to be effective strata for analyses of avian population trends (Sauer et al. 2003). Thogmartin et al. (2004b) modeled cerulean warbler abundance as a function of land use and climatic influences in the Prairie-Hardwood Transition BCR (BCR23). BCRs were also effective strata for mapping predicted abundances of five species of grassland birds as a function of land-use and climate variables (Thogmartin et al. 2006).

Modern GIS software and computers allow complex spatial habitat models to be fitted for bird populations in BCRs across North America. We evaluated the influence of largescale land-use and climatic variables on wetland breeding bird populations in the Canadian section of Bird Conservation Region 11 (CA-BCR11), the Prairie Potholes. We used bird abundance data from the NABBS, landeover data from the Prairie Farm and Rehabilitation Administration, and climate data from the National Climatic Data and Information Archive to model relative bird abundance as a function of environmental variables at a 100000 ha spatial scale in CABCR11. Results from this study will reveal land-use and climatic influences on wetland bird populations at a regional scale within CA-BCR11.

\section{Methods}

\section{Study area}

BCR 11 covers over $715000 \mathrm{~km}^{2}$ across five states in the United States and three Canadian provinces; however, this study only examined the portion within Canada (Fig. 1) because of a lack of continuous land-cover data across countries. The pothole landscape of BCR11 was formed approximately 12000 years ago after glaciers melted and left behind depressions that collected rain and snow melt (Leitch 1989). Large fluctuations in hydrologic regimes in BCR11 cause vegetation composition to vary widely. Submergent vegetation dominates in locations deep enough to have standing water during the dry season. Central zones within wetlands that periodically dry contain mid-height and tall emergents. Vernal potholes primarily support grasses, sedges, and forbs (Kantrud 1989). Agriculture has adversely affected the area ecologically with native habitat destruction and runoff (Euliss et al. 1999). Although the human population in BCR11 is generally sparse, farms continue to increase in size and urban areas are expanding (Leitch 1989). Increases in urbanization and a concomitant increase in road construction negatively impact the ecology of BCR11 (Euliss et al. 1999). Before European settlement, the region consisted of approximately $10 \%$ wetland (Mitsch and Gosselink 2000); however, agricultural practices have drained over half of the pre-existing wetlands (Leitch 1989). Agriculture-induced sedimentation, large inputs of nutrients, and agricultural chemicals have heavily impacted remaining wetlands (Euliss et al. 1999).

The climate of BCR11 is characterized by both precipita- 
Fig. 1. Distribution and tesselation of 133 North American Breeding Bird Survey (NABBS) routes in the Canada section of Bird Conservation Region 11.

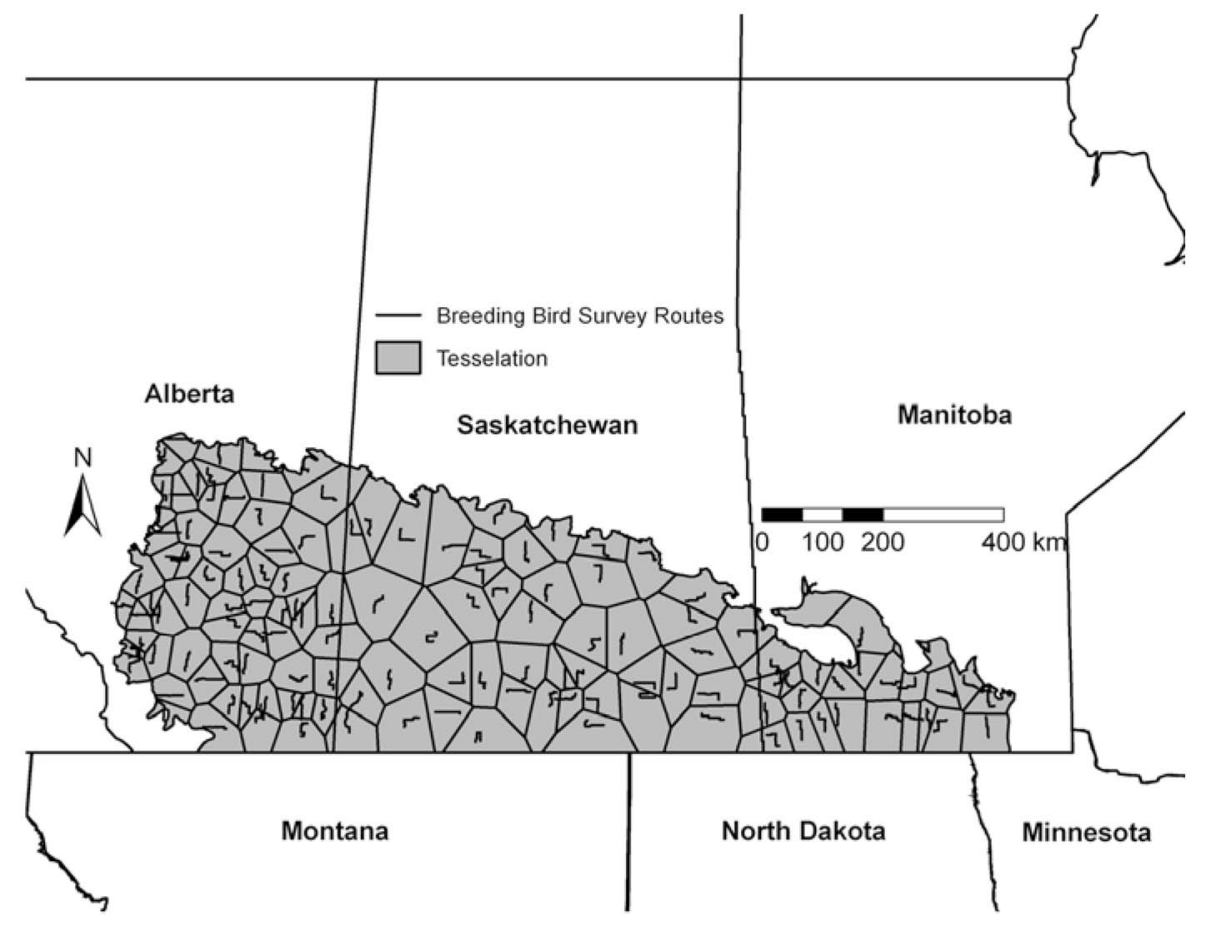

tion and temperature extremes, with the region being colder and wetter to the north and east and warmer and drier to the west and south (Kantrud 1989). Precipitation amounts vary across the region, but all locations within BCR11 have a negative water balance. Temperatures in BCR11 are generally cold with mean daily temperatures at or below $0{ }^{\circ} \mathrm{C}$ for 5 months of the year. Air temperatures in the winter can drop below $-60{ }^{\circ} \mathrm{C}$ and can exceed $40{ }^{\circ} \mathrm{C}$ during the summer (Euliss et al. 1999).

\section{Historical data sets}

This study used data from several pre-existing, large-scale data sets. Bird abundance data were obtained from NABBS routes within CA-BCR11 (Sauer et al. 2005). Climate data for Canada were obtained from the National Climatic Data and Information Archive (Environment Canada 2002). Land-cover data for Canada were used from the Prairie Farm and Rehabilitation Administration generalized landcover data set (Ashton 2001). Information from these data sets was used in conjunction with a hierarchical spatial count model to model relative bird abundance as a function of environmental covariates.

The NABBS is a long-term survey effort to monitor bird population trends within North America. Breeding bird survey routes are surveyed every year during late May and June along randomly assigned roadsides across North America. Routes are $39.4 \mathrm{~km}$ in length, with 50 stops spaced approximately every $0.8 \mathrm{~km}$ along the route. Each observer conducts a 3 min point count at each stop and records all birds seen or heard within a $402 \mathrm{~m}$ radius. When possible, individual routes are surveyed by the same observer each year, only under suitable weather conditions (i.e., low wind and minimal precipitation) where bird detection probabilities are not likely to be affected. This level of consistency minimizes variability in NABBS data, so real variations in trends can be detected over time. We used NABBS data between the years 1980 and 2000 because this time frame coincides with the time when land-cover data were derived from satellite imagery (Ashton 2001). In CA-BCR11, there are 133 routes for which data were used in this study (Fig. 1); data from 106 routes were used to create spatial models, while data from 27 randomly selected routes were withheld for validation.

Land-use information and metrics were derived from the generalized land-cover data set (GLCD) distributed by the Prairie Farm and Rehabilitation Administration. Land-use data from the GLCD represent conditions in Canada in the early 1990s and are not currently available for other time periods. The GLCD has a $100 \mathrm{~m} \times 100 \mathrm{~m}$ resolution, which only permits landscape analyses at coarse resolutions. Landuse patterns were evaluated within a $10 \mathrm{~km}$ buffer ( $\sim 100000 \mathrm{ha})$ surrounding each $39.4 \mathrm{~km}$ NABBS route. Land-use metrics were quantified within each buffer around each route using ArcGIS ${ }^{\circledR}$ version 9.1 (Environmental Systems Research, Inc. 2005) and FRAGSTATS (McGarigal et al. 2002) (Table 1). Raster algebra was used to multiply the GLCD reclassifications with each buffer; the resulting grid contained only land-use data within each buffer surrounding each route. Land-use metrics within each buffer zone surrounding NABBS routes were calculated using FRAGSTATS (McGarigal et al. 2002).

Weather data were obtained from 245 recording stations across BCR11 in both the United States and Canada. Data for Canada were used with those from the United States as part of another study to evaluate bird-environment relationships in the United States region of BCR11 (G.M. Forcey, 
Table 1. A priori environmental variables included in the suites of candidate models for each species.

\begin{tabular}{|c|c|c|c|}
\hline $\begin{array}{l}\text { Type of } \\
\text { variable }\end{array}$ & Variable & Variable description & Species that variable was modeled \\
\hline \multirow[t]{4}{*}{ Climate } & Previous year precipitation & $\begin{array}{l}\text { Total precipitation from the year prior } \\
\text { to when bird abundance was measured }\end{array}$ & All species \\
\hline & Yearly precipitation & $\begin{array}{l}\text { Total precipitation from the same year bird } \\
\text { abundance was measured }\end{array}$ & All species \\
\hline & Spring precipitation & $\begin{array}{l}\text { Total spring precipitation from the same } \\
\text { year that bird abundance was measured }\end{array}$ & BWTE, RUDU, PBGR, BLTE \\
\hline & Spring temperature & $\begin{array}{l}\text { Mean spring temperature from the same } \\
\text { year bird abundance was measured }\end{array}$ & All species \\
\hline \multirow{8}{*}{$\begin{array}{l}\text { Patch-level } \\
\text { land cover }\end{array}$} & Cropland $(\%)$ & Percentage of cropland in the landscape & MALL, BWTE, RWBL \\
\hline & Shrubland $(\%)$ & Percentage of shrubland in the landscape & MAWR \\
\hline & Trees $(\%)$ & $\begin{array}{l}\text { Percentage of tree cover in the landscape } \\
\text { (includes deciduous and coniferous trees) }\end{array}$ & RUDU, BLTE, MAWR, RWBL \\
\hline & Tree-edge density & Amount of tree edge per hectare & YHBL, COGR \\
\hline & Water $(\%)$ & Percentage of open water in the landscape & MALL, BWTE, RUDU, PBGR, BLTE \\
\hline & $\begin{array}{l}\text { Water interspersion and } \\
\text { juxtaposition index }\end{array}$ & $\begin{array}{l}\text { Percentage of land-use types that are } \\
\text { adjacent to open water }\end{array}$ & BWTE, RUDU, PBGR, BLTE \\
\hline & Water largest patch index $(\%)^{\alpha}$ & $\begin{array}{l}\text { Percentage of total landscape consisting } \\
\text { of the largest patch of open water }\end{array}$ & PBGR, BLTE \\
\hline & Wetland (\%) & $\begin{array}{l}\text { Percentage of vegetated wetland in } \\
\text { the landscape }\end{array}$ & All species \\
\hline $\begin{array}{l}\text { Landscape-level } \\
\text { land cover }\end{array}$ & Simpson's diversity index ${ }^{d}$ & Diversity of land uses in the landscape & MALL, BWTE, RWBL, COGR \\
\hline
\end{tabular}

Note: All covariates were standardized with a mean of 0 and a SD of 1. MALL, mallard (Anas platyrhynchos); BWTE, blue-winged teal (Anas discors); RUDU, ruddy duck (Oxyura jamaicensis); PBGR, pied-billed grebe (Podilymbus podiceps); NOHA, northern harrier (Circus cyaneus); BLTE, black tern (Chlidonias niger); MAWR, marsh wren (Cistothorus palustris); RWBL, red-winged blackbird (Agelaius phoeniceus); YHBL, yellow-headed blackbird (Xanthocephalus xanthocephalus); COGR, common grackle (Quiscalus quiscula).

"Largest patch index equals the area of the largest patch of a particular land use divided by the total landscape area and multiplied by 100.

${ }^{h}$ Interspersion and juxtaposition index is approximately 0 when a particular land-use type is adjacent to only one other land-use type. Interspersion and juxtaposition index equals 100 when a particular land-use type is equally adjacent to all other land-use types.

'Contagion is approximately 0 when every grid cell is a different land-use type. The contagion index equals 100 when the landscape consists of a single landuse type. This metric is similar to the interspersion and juxtaposition index except that contagion is based on cell adjacencies and not land-use type adjacencies.

${ }^{d}$ Simpson's diversity index represents the chance that any two grid cells selected at random would be different land-use types.

G.M. Linz, W.E. Thogmartin, and W.J. Bleier, unpublished data). Total precipitation (snowfall combined with rainfall) for the United States was not provided, so total precipitation for the United States was calculated as follows: total precipitation $=$ rainfall $+(0.1 \times$ snowfall $)$. This equation approximates the amount of liquid precipitation as one-tenth of the amount of snowfall, which is a common conversion factor (Akinremi et al. 1999). Weather data for Canada were provided as daily summaries of temperature and precipitation information. To ensure compatibility between monthly weather data from the United States and daily data from
Canada, we converted daily information from Canada into monthly summaries by averaging temperature and summing precipitation data for each month from 1980 to 2000.

We used the kriging function of the spatial analyst extension of ArcGIS version 9.1 (Environmental Systems Research, Inc. 2005) to create a continuous surface for each climate variable from 1980 to 2000 over BCR11 (Table 1). Kriging is a geostatistical method of surface interpolation that uses information from known points to estimate values on a grid where information is not known. This allowed us to estimate the values of climate variables around NABBS 
routes from data collected at surrounding weather stations. Grid-cell values within $10 \mathrm{~km}$ buffers surrounding each NABBS route were averaged to compute a value for each weather variable for each route for each year. Resolution of climate grids was $1000 \mathrm{~m} \times 1000 \mathrm{~m}$.

\section{Modeling approach}

Wetland bird abundance was modeled as a function of nuisance effects, land-use variables, and climatic influences using a hierarchical modeling approach within a Bayesian framework. Hierarchical models are useful for modeling NABBS data because they acknowledge correlation among multiple observational units that are present in the survey design. Spatial correlation is present in count data among routes, and temporal correlation is present in count data among years. Spatial correlation is when count similarity is tied to geographical proximity; temporal correlation occurs when count similarity is tied to survey chronology. A Bayesian approach treats all unknown quantities as random variables and therefore provides a natural approach for fitting hierarchical models (Link and Sauer 2002).

We used Poisson regression to model bird abundance as a function of environmental covariates in CA-BCR11 because counts are discrete positive values and are often Poissondistributed. Models were fitted using Markov chain Monte Carlo (MCMC) techniques using Gibbs sampling (Link et al. 2002). Gibbs sampling is an algorithm that samples the posterior distribution of a random variable (Gelman et al. 2004). Three MCMC chains were computed for each simulation with different starting values for each chain to allow computation of the Gelman-Rubin test for convergence (Brooks and Gelman 1998). MCMC simulations were run for 25000 iterations, including a 20000 iteration burn in period required for convergence. Convergence provides a period where dependence on the prior is minimized and the data primarily influence the posterior distribution. We fitted spatial models using WinBUGS version 1.4.1, which provides a means to run MCMC simulations using Gibbs sampling (Spiegelhalter et al. 2003).

We used data from 1070 NABBS counts surveyed by 162 observers from 1980 to 2000 to model bird abundance as a function of environmental covariates in CA-BCR11. The response variable in the models is the total number of birds across the entire route for each year for each species. The hierarchical model accounted for nuisance effects at three levels in a hierarchy. Inherent temporal variation in bird abundance over time was accounted for with a year effect and a trending term. Two observer effects were included in the model: one accounted for differences in surveying abilities among observers (Sauer et al. 1994) and the other effect accounted for inexperience (a first time observer effect). The first time observer effect is a binary variable with a value of 0 if it was an observer's first time surveying a given route and 1 if the observer had previously surveyed the route. Inexperienced observers are often less familiar with species found on their route and less efficient at completing the survey than more experienced observers (Kendall et al. 1996). Spatial autocorrelation in counts occurs because routes that are closer in proximity may have similar habitat characteristics and concomitantly similar species composition and abundance. Spatial autocorrelation was accounted for with a spatial conditional autoregressive (CAR) prior distribution on the route effect in the model (Banerjee et al. 2004). We derived an adjacency matrix (Lawson et al. 2003) for NABBS routes within CA-BCR11 by creating a tessellation of NABBS routes within CA-BCR11 and forming an irregular lattice (Hooge and Eichenlaub 1997) (Fig. 1). Spatial autocorrelation is accounted for when routes share a common boundary in the tessellation; distances among routes are not taken into account, although in other formulations this is possible (Thogmartin et al. 2004b).

One unique aspect of Bayesian analyses is the inclusion of prior beliefs or information that influences the final outcome. This prior information can be either vague or specific. Because little information is known about how environmental variables $\left(x_{k}\right)$ influence wetland birds at the regional level, vague prior distributions were assigned to parameters in the model (Link and Sauer 2002). Breeding bird survey counts $(\lambda)$ occurred across space $(s)$. Year $\left(\gamma_{k}\right)$ and observer $(\omega)$ effects were given mean zero normal distributions; beta parameters $\left(\xi_{k}\right)$, spatial effects $(Z)$, and novice effects $(\eta)$ were given normal distributions with a mean of 0 and a variance equal to 1000 (Link and Sauer 2002; Thogmartin et al. 2004b). The final model used was $\log \lambda(s)=\sum_{k=1}^{n} \xi_{k} x_{k}(s)+Z_{k}(s)+\omega_{k}(s)+\eta I(s)+\gamma_{k}(s)$. Thogmartin et al. $(2004 b, 2006)$ used this hierarchical model to examine effects of environmental covariates on cerulean warblers and five grassland bird species. This model did not include an effect for overdispersion $\left(\epsilon_{k}\right)$ because the focal species in our study were not as overdispersed as the rare species examined by Thogmartin et al. $(2004 b, 2006)$.

Remote-sensing technology can measure a large suite of environmental variables over large geographic regions. We reviewed published habitat associations and life histories for wetland birds in this study to determine which environmental variables would likely have the most effect on abundance (Table 1). Variables that were thought to be important descriptors of bird abundance were selected a priori. Selecting variables a priori reduces the chance of finding spurious effects that can occur when examining a large suite of covariates. Selected variables were used to construct candidate sets of models for each focal species. Spearman rank correlations were calculated for environmental covariates; covariates with a correlation coefficient $>0.5$ were not included in the same a priori model.

Life history was evaluated for mallard (Drilling et al. 2002), blue-winged teal (Anas discors L., 1766) (Rohwer et al. 2002), ruddy duck (Oxyura jamaicensis (Gmelin, 1789)) (Brua 2002), pied-billed grebe (Podilymbus podiceps (L., 1758)) (Muller and Storer 1999), northern harrier (Circus cyaneus (L., 1766)) (MacWhirter and Bildstein 1996), black tern (Chlidonias niger (L., 1758)) (Dunn and Agro 1995), marsh wren (Cistothorus palustris (Wilson, 1810)) (Kroodsma and Verner 1997), red-winged blackbird (Yasukawa and Searcy 1995), yellow-headed blackbird (Xanthocephalus xanthocephalus (Bonaparte, 1826)) (Twedt and Crawford 1995), and common grackle (Quiscalus quiscula (L., 1758)) (Peer and Bollinger 1997). This group of species represented a variety of wetland bird taxa, and their behaviors are conducive to being well represented in NABBS. Habitat descriptions of each species were studied in each 
Table 2. Posterior distributions of explanatory variables in the best subset of models for explaining wetland bird abundance in the Canada section of Bird Conservation Region 11.

\begin{tabular}{|c|c|c|c|c|c|}
\hline \multirow[b]{2}{*}{ Species } & \multirow[b]{2}{*}{ Variable } & \multirow[b]{2}{*}{$\operatorname{Mean}^{a}$} & \multicolumn{2}{|c|}{$95 \%$ credibility interval } & \multirow{2}{*}{$\begin{array}{l}\text { Variable } \\
\text { importance }^{b}\end{array}$} \\
\hline & & & Lower & Upper & \\
\hline \multirow[t]{10}{*}{ Mallard } & Previous spring temperature & 0.228 & 0.206 & 0.249 & 1.000 \\
\hline & Previous yearly precipitation & 0.141 & 0.121 & 0.162 & 1.000 \\
\hline & Cropland area $(\%)$ & 0.609 & 0.380 & 0.828 & 0.743 \\
\hline & Forage area $(\%)$ & 0.002 & -0.328 & 0.362 & 0.095 \\
\hline & Water area $(\%)$ & 0.073 & -0.198 & 0.353 & 0.190 \\
\hline & Wetland area $(\%)$ & 0.314 & 0.120 & 0.510 & 0.596 \\
\hline & Wetland interspersion and juxtaposition & 0.151 & -0.020 & 0.334 & 0.202 \\
\hline & Contagion & -0.136 & -0.366 & 0.073 & 0.202 \\
\hline & Simpson's diversity & -0.098 & -0.282 & 0.123 & 0.095 \\
\hline & Spatial conditional autoregressive & 2.678 & 2.491 & 2.881 & 1.000 \\
\hline \multirow[t]{6}{*}{ Blue-winged teal } & Yearly precipitation & 0.150 & 0.107 & 0.191 & 1.000 \\
\hline & Yearly temperature & 0.413 & 0.314 & 0.511 & 1.000 \\
\hline & Water area $(\%)$ & 0.101 & -0.218 & 0.427 & 0.726 \\
\hline & Wetland area $(\%)$ & 0.025 & -0.347 & 0.395 & 0.726 \\
\hline & Simpson's diversity & 0.044 & -0.229 & 0.306 & 0.726 \\
\hline & Spatial conditional autoregressive & 1.082 & 0.849 & 1.299 & 1.000 \\
\hline \multirow[t]{9}{*}{ Ruddy duck } & Spring precipitation & 0.205 & 0.134 & 0.277 & 1.000 \\
\hline & Spring temperature & 0.121 & 0.037 & 0.203 & 1.000 \\
\hline & Tree area $(\%)$ & 0.151 & -0.544 & 1.006 & 0.386 \\
\hline & Water area $(\%)$ & -0.207 & -0.963 & 0.624 & 0.386 \\
\hline & Wetland area $(\%)$ & 0.064 & -0.828 & 0.831 & 0.386 \\
\hline & Water interspersion and juxtaposition & 0.079 & -0.555 & 0.644 & 0.308 \\
\hline & Wetland interspersion and juxtaposition & 0.055 & -0.474 & 0.578 & 0.308 \\
\hline & Contagion & 0.082 & -0.590 & 0.634 & 0.308 \\
\hline & Spatial conditional autoregressive & -1.777 & -2.134 & -1.435 & 1.000 \\
\hline \multirow[t]{9}{*}{ Pied-billed grebe } & Previous spring temperature & -0.202 & -0.331 & -0.077 & 1.000 \\
\hline & Previous yearly precipitation & 0.390 & 0.241 & 0.538 & 1.000 \\
\hline & Water area $(\%)$ & 0.127 & -0.312 & 0.577 & 0.207 \\
\hline & Wetland area $(\%)$ & 0.189 & -0.256 & 0.647 & 0.483 \\
\hline & Water largest patch & -0.157 & -0.572 & 0.244 & 0.276 \\
\hline & Water interspersion and juxtaposition & -0.114 & -0.502 & 0.276 & 0.366 \\
\hline & Wetland interspersion and juxtaposition & 0.267 & -0.112 & 0.627 & 0.366 \\
\hline & Contagion & 0.128 & -0.260 & 0.517 & 0.573 \\
\hline & Spatial conditional autoregressive & -1.830 & -2.256 & -1.438 & 1.000 \\
\hline \multirow[t]{7}{*}{ Northern harrier } & Previous year spring temperature & -0.026 & -0.109 & 0.054 & 0.776 \\
\hline & Previous year precipitation & 0.150 & 0.056 & 0.244 & 0.999 \\
\hline & Forage largest patch & -0.131 & -0.314 & 0.050 & 0.272 \\
\hline & Wetland area $(\%)$ & 0.050 & -0.092 & 0.191 & 0.258 \\
\hline & Wetland largest patch & 0.057 & -0.080 & 0.200 & 0.237 \\
\hline & Contagion & 0.019 & -0.130 & 0.173 & 0.321 \\
\hline & Spatial conditional autoregressive & 0.195 & 0.004 & 0.377 & 1.000 \\
\hline \multirow[t]{5}{*}{ Black tern } & Spring temperature & 0.252 & 0.204 & 0.300 & 1.000 \\
\hline & Yearly precipitation & 0.315 & 0.266 & 0.363 & 1.000 \\
\hline & Water largest patch & -0.103 & -0.552 & 0.298 & 1.000 \\
\hline & Wetland largest patch & 0.556 & 0.132 & 1.033 & 1.000 \\
\hline & Spatial conditional autoregressive & -0.111 & -0.419 & 0.136 & 1.000 \\
\hline \multirow[t]{8}{*}{ Marsh wren } & Spring temperature & 0.270 & 0.164 & 0.376 & 1.000 \\
\hline & Yearly precipitation & 0.025 & -0.111 & 0.167 & 0.540 \\
\hline & Shrubland area $(\%)$ & -0.270 & -0.810 & 0.214 & 0.200 \\
\hline & Water interspersion and juxtaposition & -0.123 & -0.754 & 0.510 & 0.313 \\
\hline & Wetland area $(\%)$ & 0.330 & -0.208 & 0.804 & 0.313 \\
\hline & Contagion & -0.926 & -1.704 & -0.246 & 1.000 \\
\hline & Patch richness density & -0.026 & -0.664 & 0.596 & 0.227 \\
\hline & Spatial conditional autoregressive & -3.253 & -3.856 & -2.704 & 1.000 \\
\hline
\end{tabular}


Table 2 (concluded).

\begin{tabular}{|c|c|c|c|c|c|}
\hline \multirow[b]{2}{*}{ Species } & \multirow[b]{2}{*}{ Variable } & \multirow[b]{2}{*}{ Mean $^{a}$} & \multicolumn{2}{|c|}{$95 \%$ credibility interval } & \multirow{2}{*}{$\begin{array}{l}\text { Variable } \\
\text { importance }^{b}\end{array}$} \\
\hline & & & Lower & Upper & \\
\hline \multirow[t]{6}{*}{ Red-winged blackbird } & Previous spring temperature & 0.034 & 0.019 & 0.049 & 1.000 \\
\hline & Previous yearly precipitation & 0.029 & 0.015 & 0.043 & 1.000 \\
\hline & Forage area $(\%)$ & 0.059 & -0.111 & 0.222 & 1.000 \\
\hline & Wetland interspersion and juxtaposition & 0.028 & -0.117 & 0.173 & 1.000 \\
\hline & Patch richness density & -0.064 & -0.203 & 0.063 & 1.000 \\
\hline & Spatial conditional autoregressive & 3.708 & 2.954 & 3.935 & 1.000 \\
\hline \multirow[t]{5}{*}{ Yellow-headed blackbird } & Previous yearly precipitation & 0.118 & 0.088 & 0.147 & 1.000 \\
\hline & Yearly temperature & 0.474 & 0.397 & 0.558 & 1.000 \\
\hline & Tree-edge density & -0.306 & -0.681 & 0.109 & 0.390 \\
\hline & Wetland area $(\%)$ & 0.379 & 0.000 & 0.721 & 0.725 \\
\hline & Spatial conditional autoregressive & 1.620 & 1.406 & 1.819 & 1.000 \\
\hline \multirow[t]{8}{*}{ Common grackle } & Previous spring temperature & 0.157 & 0.085 & 0.233 & 1.000 \\
\hline & Previous yearly precipitation & -0.015 & -0.081 & 0.052 & 0.352 \\
\hline & Other land area $(\%)$ & -0.167 & -0.514 & 0.176 & 1.000 \\
\hline & Tree-edge density & -0.136 & -0.495 & 0.211 & 1.000 \\
\hline & Wetland area $(\%)$ & -0.047 & -0.316 & 0.247 & 0.352 \\
\hline & Contagion & 0.085 & -0.206 & 0.435 & 0.208 \\
\hline & Simpson's diversity & -0.202 & -0.513 & 0.142 & 0.393 \\
\hline & Spatial conditional autoregressive & -0.322 & -0.588 & -0.071 & 1.000 \\
\hline
\end{tabular}

"Mean values represent model averaged values of the 3 parameters based on the values of the 3 parameters in each model and the corresponding weight $\left(w_{i}\right)$ of each model (Burnham and Anderson 2002, p. 152).

"Variable importance is calculated by summing model weights for each model containing the variable of interest. The spatial conditional autoregressive term always has a value of 1 , because it was a priori believed to be important all the time and was included in every candidate model.

species account. Based on this documentation, we selected environmental variables that would likely be positively or negatively associated with the abundance of each species. Variables were combined in different configurations to form the models in our a priori candidate sets. We standardized all environmental variables to have a mean of 0 and a SD of 1. Standardization not only improves MCMC convergence, but also allows comparison of the slopes in the model to assess the relative importance of each variable (Gilks and Roberts 1996).

We used the deviance information criterion (DIC) to rank models relative to one another (Spiegelhalter et al. 2002). Inference was constrained to models that were within 4 DIC units of the best model, which approximates a $95 \%$ confidence set of best models (Burnham and Anderson 2002, p. 170). Model weights and variable importance measures were calculated to assess the relative importance of each model and variable, respectively. We also modeled null models (which contained no environmental variables, only nuisance variables) to provide a reference point to ascertain the degree to which environmental variables improved model fit.

After completing analyses of the models identified a priori, we conducted post hoc analyses to determine if other models provided a better fit to the data. We evaluated slope coefficients and 95\% Bayesian credibility intervals to determine the relative strengths of variables that were already determined to be important from models fitted from the a priori candidate set. We created several additional models for each species that contained variables whose 95\% credibility intervals did not overlap zero as determined in the a priori model fitting. This allowed us to examine additional models that may provide a better fit to the data, but that were not modeled in the a priori candidate set. Models identified post hoc that had a lower DIC value than the best a priori model were included in the results.

\section{Model evaluation}

Data from 27 NABBS routes in CA-BCR 11 were withheld from model construction so that known abundance information from these routes could be compared with estimated abundances generated from the best model. WinBUGS calculated abundances for routes that were withheld using prior information, information in the data, the value of the beta parameters, and nuisance effects (year, route, observer) in the model. Abundance values calculated from withheld routes were compared with known information using simple linear regression. Our models were evaluated using two aspects of model validation: discrimination and calibration. We compared the ability of the model to predict abundance by comparing the slopes of the regression line to a $1: 1$ correspondence line (calibration) and by examining the $R^{2}$ values of the regression line (discrimination). All regression analyses were performed using R (R Development Core Team 2005).

\section{Relative abundance mapping}

We created spatial maps of bird abundance across CABCR11 for each focal species in our study. Spatial models were based on model-averaged beta parameters in each model (Burnham and Anderson 2002). Data layers in the GIS were standardized before creating maps of bird abundance because the same covariates were standardized prior to MCMC simulation. Mapping was performed using a regular 100000 ha lattice over CA-BCR11 that corresponded to 
Fig. 2. Predicted relative abundances for selected wetland bird species in the Canada section of Bird Conservation Region 11, the Prairie Potholes. Differences in the color of shaded regions should be treated as differences in relative abundance.

the spatial extent examined in the study. We computed metrics for environmental covariates that were in the suite of best models for each species in each lattice cell. Final maps of avian abundance had a resolution of $1000 \mathrm{~m} \times 1000 \mathrm{~m}$ $\left(1 \mathrm{~km}^{2}\right)$ and were computed using the raster calculator in the spatial analyst extension of ArcGIS ${ }^{12}$ version 9.1 (Environmental Systems Research, Inc. 2005).

\section{Results}

Environmental covariates substantially improved model fit for each species compared with the null models that did not contain environmental variables (Appendix A, Table A1). Climatic variables contributed the most to improving model fit, followed by land-use composition variables and landscape configuration predictors. All models in the best subset contained climatic predictors; however, the same was not true with landscape variables (Table A1). Generally, landuse and landscape configuration predictors had small to almost no effects on wetland breeding birds in CA-BCR11, as slope coefficients were small and most $95 \%$ credibility intervals overlapped zero (Table 2). Spatial structure (spatial conditional autoregressive variable) had strong effects for all species except the black tern, and its effect was stronger than any of the environmental covariates (Table 2). We considered a variable as having a strong effect if its $95 \%$ credibility interval did not overlap zero. Post hoc analyses revealed models with better fit than a priori models for mallard, northern harrier, marsh wren, and yellow-headed blackbird (Table A1).

Model selection uncertainty was relatively high for mallard, with five models competing with the best model. The best model was weighted at 0.406 , which was substantially higher than the next best model in the candidate set (Table A1). The variables having the strongest influence on mallard abundance were previous year spring temperature, previous year yearly precipitation, cropland area, and wetland area; all of these variables were positively associated with mallard abundance (Table 2). The mallard relative abundance map predicted mallards to be moderately abundant across CABCR11, with localized high densities in the central region (Fig. 2). Only two models were in the best subset for bluewinged teal, with the best model having a weight of 0.726 , indicating strong support. The other model in the best subset contained only climatic variables and both climatic variables were also found in the best model (Table A1). Climatic influences were the strongest factors influencing blue-winged teal abundance; land-use variables had little effect (Table 2). Blue-winged teal were locally abundant in the north-central part of CA-BCR11, with lesser numbers occurring elsewhere (Fig. 2).

Two models competed with the best model for ruddy ducks, with all three models weighted almost equally; the best model weight was 0.386 (Table A1). Spring temperature and spring precipitation were the only covariates that had strong effects on ruddy duck abundance. Although other covariates were in the candidate model set, the strength of their effects was weak (Table 2). Predicted ruddy duck abundance was low across CA-BCR11, with localized high densities expected in the north-central portion of CABCR11 (Fig. 2).

Pied-billed grebes were not strongly affected by environmental covariates, with only previous year precipitation having a strong influence on abundance (Table 2). Moderate model uncertainty existed for pied-billed grebes, with four models in the best subset. Relative abundance of pied-billed grebes was predicted to be low across much of CA-BCR11, with scattered localized concentrations present in the northcentral portion of the region (Fig. 2).

Model selection uncertainty was high for northern harriers, with seven models being in the best subset. The top two models contained only climate predictors and their combined weight was 0.407 (Table A1). Evaluation of model coefficients showed that previous year precipitation was the only variable to have a strong influence on bird abundance (Table 2). The highest concentrations of northern harrier abundance occurred in the south-central portion of CABCR11, with lower relative abundance occurring in other areas (Fig. 2).

There was no model uncertainty for black terns within CA-BCR11. The best model with spring temperature, yearly precipitation, water largest patch index, and wetland largest patch index as covariates had a model weight of 1.0 (Table A1). Additionally, all covariates except water largest patch index had strong effects on black tern abundance (Table 2). The strong effect of wetland largest patch index indicated some degree of area sensitivity for this species. Localized areas of high predicted abundance occurred in the northcentral and northwestern portions of CA-BCR11 (Fig. 2).

Three models competed with the best model for predicting marsh wren abundance in CA-BCR11 (Table A1). Marsh wrens were affected strongly by spring temperature but not by precipitation (Table 2). Marsh wrens were also strongly affected by the contagion index in CA-BCR11. Predicted marsh wren abundance was fairly uniform, with a strong localized concentration in the eastern region of CABCR1 1 (Fig. 2).

Model uncertainty was nonexistent for red-winged blackbirds, with the best model weighted at 1.0 (Table A1). Redwinged blackbirds were strongly influenced by previous year spring temperature and previous year precipitation (Table 2). Predicted relative red-winged blackbird abundance was fairly uniform across CA-BCR11, with the lowest densities occurring in the midwestern portion of the region (Fig. 2).

Only three models were in the best subset for yellowheaded blackbirds and the best model had a weight of 0.390 (Table A1). Previous year precipitation, yearly temperature, and wetland area had strong effects on yellow-headed blackbird abundance (Table 2). The highest predicted abundances for yellow-headed blackbirds occurred in the eastern-central portions of CA-BCR11, with lower abundances predicted to occur elsewhere (Fig. 2).

Model uncertainty was present in the best subset of the model for common grackles, with the best model being 


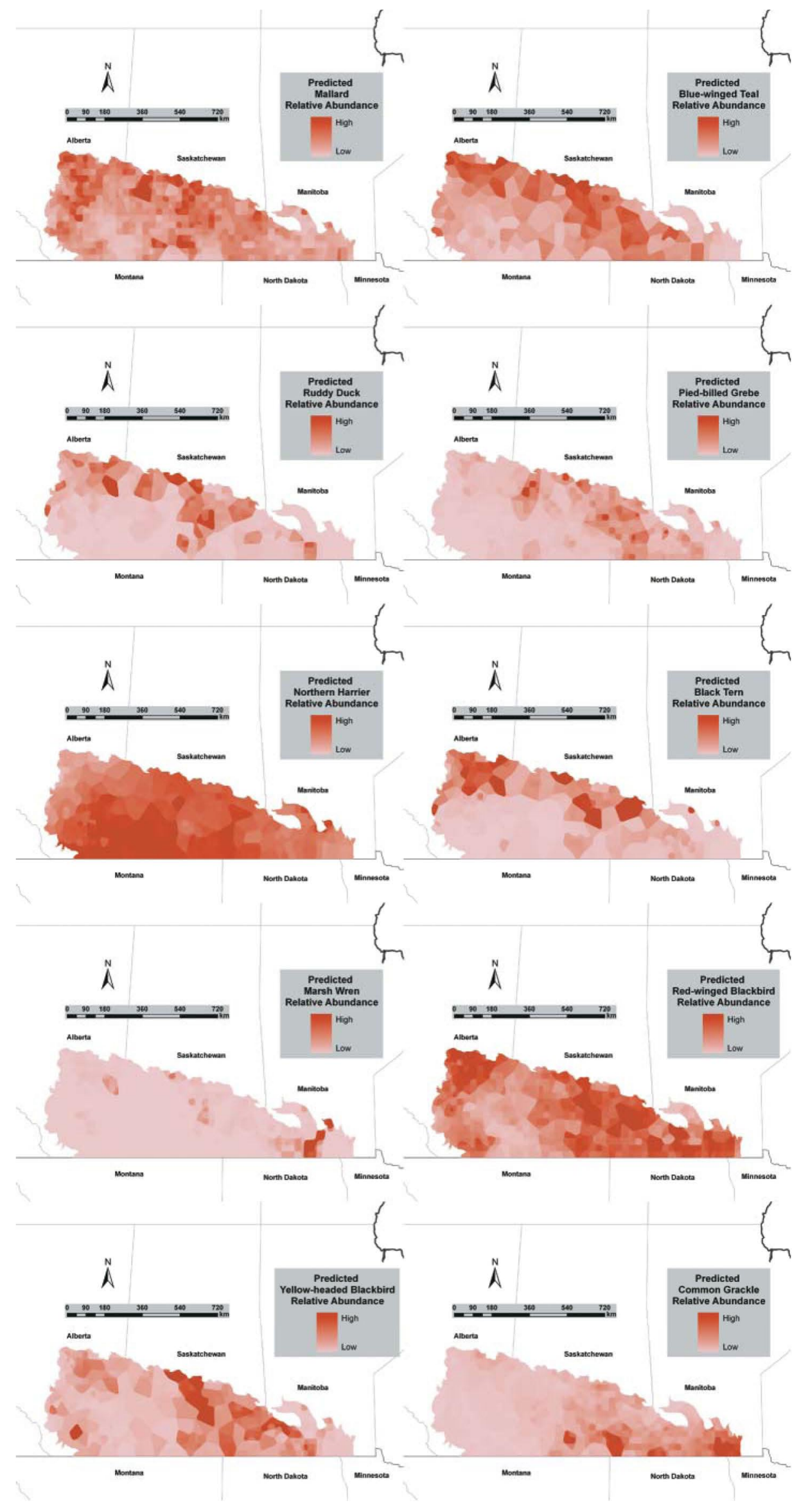


Fig. 3. Simple linear regression plots validating spatial models for predicting bird abundance in the Canada section of Bird Conservation Region 11 ( $n=169, P<0.01$ for each species). The solid line represents the least squares regression line and the broken line represents a $1: 1$ correspondence line. Observed bird abundances are on the $y$ axes and expected bird abundances are on the $x$ axes.

weighted at 0.393 (Table A1). Previous year spring temperature was the only covariate to have a strong influence on common grackle abundance (Table 2). The predicted relative abundance map suggests that common grackles are most likely to be abundant in the south-central and eastern regions of CA-BCR 11 (Fig. 2).

\section{Model validation}

The discrimination component of our model validation showed that models had poor to good fit $\left(R^{2}=0.03-0.47\right)$ depending on the species. Despite good predictions for some species, the calibration component of our validation showed that the model both underpredicted and overpredicted bird numbers throughout the range of abundance for all species. The model tended to underpredict more than overpredict, and underpredictions were most common at the lower range of abundance for each species. Some species (e.g., yellow-headed blackbird) validated well, while others such as the blue-winged teal had poor fit (Fig. 3).

\section{Discussion}

Our results revealed many relationships between environmental variables and wetland bird abundance. Climate predictors made substantial contributions to improving model fit for all species. No candidate models in the best subset lacked climate covariates. Venier et al. (2004) noted that habitat models with climate variables improved model fit compared with models without climate covariates. Temperature and precipitation have also been shown to affect bird abundance (Cotgreave 1995), as well as their distributions (Root 1988). Post hoc modeling efforts revealed additional models in the best subset that would have been overlooked if our analyses were restricted to a priori modeling. This underscores the importance of considering information revealed in the a priori analyses in further landscape modeling efforts.

Climate predictors were also shown to be important when predicting abundances of cerulean warblers and grassland birds, although the strength of the effects varied among species (Thogmartin et al. 2004b, 2006). Climate variables strongly affected abundance patterns for all four waterbirds examined in our study, which concurs with Venier et al. (2004) who showed that the inclusion of climate variables can greatly improve model fit. Abundance of all four waterbird species was positively related to precipitation and temperature variables, except for a negative relationship between previous year spring temperature and pied-billed grebe abundance. Positive relationships between climate and waterbird abundance are expected, as cold temperatures affect nesting success (Hammond and Johnson 1984) and dry conditions can reduce local waterfowl populations (Bethke and Nudds 1995). Land-use predictors strongly affected only mallards; both cropland area and wetland area were shown to be important explanatory variables. These findings can be explained by the habitat preferences of mallards, which require wetland areas for foraging (Krapu et al. 1983, 2000; Miller 2000) and dry upland areas for nesting (Drilling et al. 2002).

Northern harriers were only strongly affected by previous year precipitation, while black tern abundance was strongly influenced by spring temperature, yearly precipitation, and wetland largest patch index. The influence of previous year precipitation on northern harrier abundance can be explained by this bird's affinity for wetland habitats for breeding (MacWhirter and Bildstein 1996). The tendency of black terns to nest in semi-permanent ponds (Dunn and Agro 1995) may explain why current year climate variables have stronger effects than previous year effects. Ephemeral wetlands are more affected by recent weather than by weather events in the past. Black terns in CA-BCR11 appear to be area sensitive, owing to the stronger influence of wetland largest patch index compared with the total wetland area. This finding concurs with other studies that showed black terns require large wetlands of nearly 20 ha (Naugle et al. 2000).

Passerines examined in this study were all strongly influenced by at least one climate variable; land-use and landconfiguration variables contributed relatively less to predicting songbird abundance. All passerines were positively associated with either spring temperature, previous year spring temperature, or yearly temperature. Below average temperatures may impact nesting success because of exposure and reduction in food supplies (Root 1988, Venier et al. 1999, 2004). Positive relationships with precipitation variables are likely due to the influence of precipitation on wetland abundance and area. Land-use predictors were only important predictors of abundance for marsh wrens. Marsh wrens were likely influenced by landscape contagion, owing to their preference for mixed stands of vegetation for nesting (Kroodsma and Verner 1997).

Discrimination and calibration validation efforts showed that the ability of the model to predict abundance varied highly among species. Although some models fit the data poorly, we believe that mapping the models is useful as long as the results from model validations are considered when interpreting the maps. There were five counts for ruddy ducks and six counts for marsh wrens that were distant from the main cluster of points. The five outliers for ruddy ducks were all located on route 129 in Alberta, which is surrounded by a high proportion of woody vegetation. Ruddy ducks are not typically associated with woody vegetation (Brua 2002); however, our models identified a positive relationship between ruddy ducks and woody vegetation. Although this effect was weak $(95 \%$ Bayesian credible interval for woody vegetation overlapped zero), the disproportionate amount of woody vegetation caused the model to overpredict abundance for this species. The model overpredicted marsh wren abundance on six counts on route 207 in Manitoba, which can be attributed to the low contagion index and small shrubland abundance surrounding this route. The inverse relationship between these variables and 

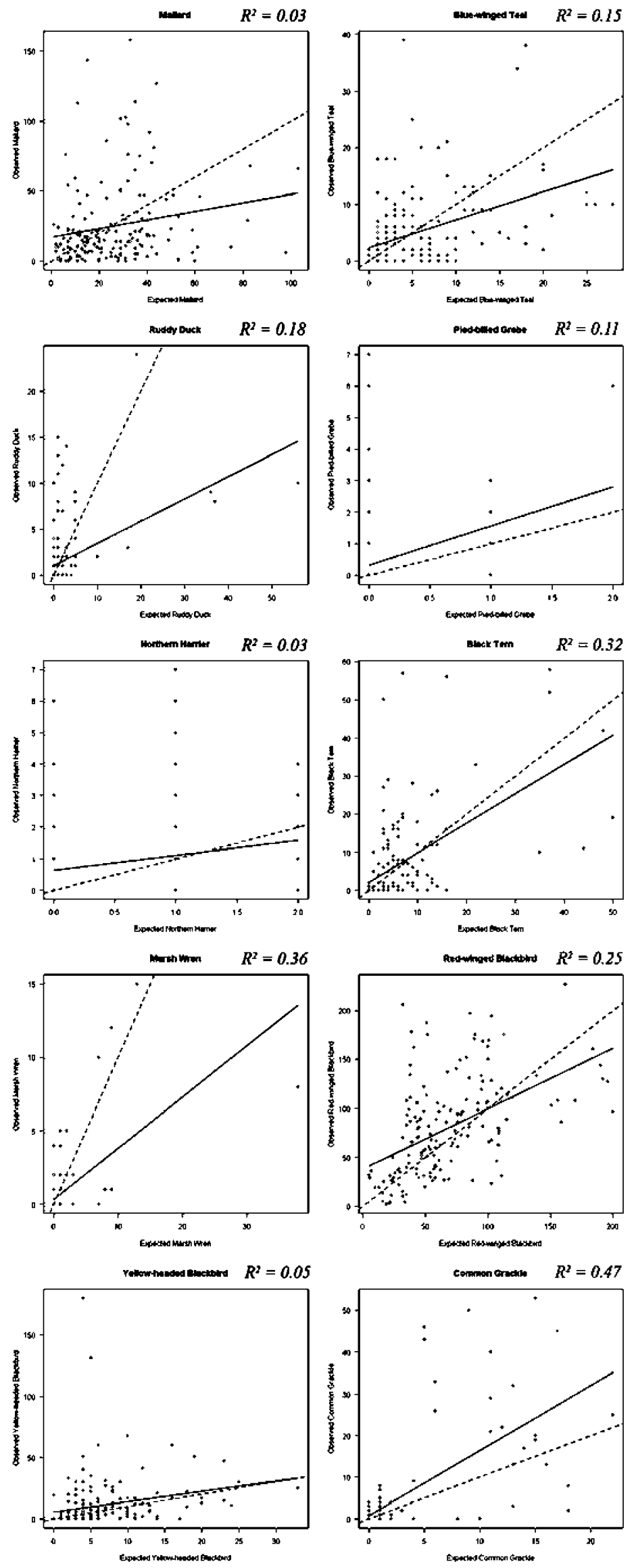
marsh wren abundance caused the model to overpredict abundance on this route.

Results of this study show that climate effects on wetland birds are stronger than almost all effects of land use. Landscape composition effects were only strong for mallards and black terns; landscape configuration variables only had strong effects on marsh wrens. This could be due to actual differences in how environmental influences affect birds or because of the data per se. Because more information is present in time-series climate data than in static land-use data, the effects of land use may appear weaker than those of climate. The greater amount of information in the timeseries data may inflate the relative strength of the effect compared with the effects of land-use data. If time-series land-cover data were available, we predict that the fit of land-use variables to bird abundance would improve. Another possibility is that wetland birds are affected by landuse variables at spatial scales other than the one examined in this analysis. Other studies (e.g., Thogmartin et al. 2004b, 2006; Forcey 2006) examined the influence of environmental covariates at three spatial scales; however, these studies used land-use data with $30 \mathrm{~m}$ resolution, which allowed the authors to examine environmental relationships at finer scales. Land-use data used in this study had $100 \mathrm{~m}$ resolution, which prevented us from reliably evaluating spatial scales smaller than $\sim 100000$ ha. At smaller scales (e.g., 1000 or 10000 ha), the larger grid-cell size of the land-use raster provides too coarse of a representation of the landscape to be useful for avian habitat modeling. A final explanation for weak land-use associations with wetland birds is because the coarse resolution of the land-use data prevents a precise representation of the actual landscape. These land-use data may be overgeneralized to the point where they cannot be used to reliably reveal landscape composition and configuration effects on wetland birds examined in this study. Classification errors in land-use data may also exacerbate this problem (Thogmartin et al. 2004a).

A final limitation that may have precluded our ability to assess wetland bird relationships with environmental covariates involves the availability of spatial data. There are many environmental variables that may be important to wetland birds for which large-scale remotely sensed data do not exist. For example, cattail is a dominant form of vegetation within wetland habitats in CA-BCR11 and likely influences the abundance of wetland birds. Water depth is also a likely factor in habitat suitability of wetland habitats, particular for waterbirds. Although these factors likely influence wetland bird habitat suitability, there are no spatial data sets for these variables over CA-BCR11 that prevents us from ascertaining their effects on wetland birds. Errors in our climate interpolations may also be present in our data and may be reducing our ability to find climate relationship with wetland birds. Errors in interpolations would be most pronounced in areas where data points were scarce and at small scales. Because of our large sample of weather-recording stations ( $n=$ 245), we suggest that large-scale errors over CA-BCR11 are unlikely and that microvariation in climate variables at small scales is not relevant for regional-scale modeling efforts.

Continued wetland draining and grassland conversion into agriculture area will increase concerns regarding wetland bird populations in CA-BCR11. Hierarchical spatial models can aid biologists and managers with wetland bird conservation and management by $(i)$ providing information on how wetland birds are affected by climate and land-use patterns and (ii) providing maps of predicted relative abundance that can suggest locations where conservation and management efforts could be focused to affect habitats that favor (or disfavor) a species of interest. Large-scale spatial models that include climate predictors may also have application in predicting the consequences of climate change on patterns in bird abundance. We suggest that our mapped models of relative abundance be validated with ancillary field data before being used to make management decisions. Despite the need for field validation, our mapped models provide baseline information on regional bird abundance and avian-habitat relationships. Wildlife managers can use this knowledge when determining locations for implementing management practices.

\section{Acknowledgements}

We are grateful for the advice provided by Mario E. Biondini, Gary. K. Clambey, and Gary. L. Nuechterlein. Suggestions for improvements to data analyses were given by David Anderson, Diane Granfors, Rex Johnson, Neal Niemuth, and John Sauer. We are also grateful to Eric O'Neal for providing ArcGIS plug-ins to simplify the spatial analyses of climate and land-use data. James Ashton provided raster land-use data for our analyses and we appreciate this contribution. Breeding bird surveys are conducted annually by thousands of volunteers and we are grateful for their efforts. This project was funded by the National Wildlife Research Center, a unit within the United States Department of Agriculture, Animal Plant and Health Inspection Service, Wildlife Services. George M. Linz was the study director for this project. Financial support was also provided by the Department of Biological Sciences and the Graduate School at North Dakota State University.

\section{References}

Akinremi, O.O., McGinn, S.M., and Cutforth, H.W. 1999. Precipitation trends on the Canadian prairies. J. Clim. 12: 2996-3003. doi:10.1175/1520-0442(1999)012<2996:PTOTCP>2.0.CO;2.

Ashton, J. 2001. PFRA generalized landcover [online]. Available from http://www.agr.gc.ca/pfra/gis/lcvmeth_e.pdf. [accessed 5 September 2005].

Banerjee, S., Carlin, B.P., and Gelfand, A.E. 2004. Hierarchical modeling and analysis of spatial data. Monographs on Statistics and Applied Probability 101. Chapman Hall, Boca Raton, Fla.

Bethke, R.W., and Nudds, T.D. 1995. Effects of climate change and land use on duck abundance in Canadian Prairie-Parklands. Ecol. Appl. 5: 588-600.

Brooks, S.P., and Gelman, A. 1998. Alternative methods for monitoring convergence of iterative simulations. J. Comput. Graph. Stat. 7: 434-455. doi:10.2307/1390675.

Brua, R.B. 2002. Ruddy duck (Oxyura jamaicensis). In The birds of North America. No. 696. Edited by A. Poole and F. Gill. The Academy of Natural Sciences, Philadelphia, Pa., and the American Ornithologists' Union, Washington, D.C.

Burnham, K.P., and Anderson, D.R. 2002. Model selection and multimodel inference: a practical information-theoretic approach. 2nd ed. Springer-Verlag, New York. 
Calder, C., Lavine, M., Muller, P., and Clark, J.S. 2003. Incorporating multiple sources of stochasticity into dynamic population models. Ecology, 84: 1395-1402.

Cotgreave, P. 1995. Weather conditions are correlated with the relation between mass and abundance in bird communities. Acta Oecol. 16: 543-552.

Clark, R.G., and Weatherhead, P.J. 1986. The effect of fine-scale variations in agricultural land use on the abundance of redwinged blackbirds. Can. J. Zool. 64: 1951-1955.

Drilling, N., Titman, R., and McKinney, F. 2002. Mallard (Anas platyrhynchos). In The birds of North America. No. 658. Edited by A. Poole and F. Gill. The Academy of Natural Sciences, Philadelphia, Pa., and the American Ornithologists' Union, Washington, D.C.

Dunn, E.H., and Agro, D.J. 1995. Black tern (Chlidonias niger). In The birds of North America. No. 147. Edited by A. Poole and F. Gill. The Academy of Natural Sciences, Philadelphia, Pa., and the American Ornithologists' Union, Washington, D.C.

Environment Canada. 2002. Canadian daily climate data CDs [online]. Available from http://www.climate.weatheroffice.ec.gc.ca/ prods_servs/cded_iso_e.html [accessed 13 January 2006].

Environmental Systems Research, Inc. 2005. ArcGIS Version 9.1 [computer program]. Environmental Systems Research, Inc., Redlands, Calif.

Euliss, N.H., Jr., Mushet, D.M., and Wrubleski, D.A. 1999. Wetlands of the Prairie Pothole Region: invertebrate species composition, ecology, and management. In Invertebrates in freshwater wetlands of North America: ecology and management. Chapter 21. Edited by D.P. Batzer, R.B. Rader, and S.A. Wissinger. John Wiley and Sons, New York. pp. 471-514.

Fairbairn, S.E., and Dinsmore, J.J. 2001. Local and landscape-level influences on wetland bird communities of the Prairie Pothole Region of Iowa, USA. Wetlands, 21: 41-47. doi:10.1672/02775212(2001)021 [0041:LALLIO]2.0.CO;2.

Flather, C.H., and Sauer, J.R. 1996. Using landscape ecology to test hypotheses about large-scale abundance patterns in migratory birds. Ecology, 77: 28-35. doi:10.2307/2265651.

Forcey, G.M. 2006. Landscape-level influences on wetland birds in the Prairie Pothole Region of the United States and Canada. Ph.D. dissertation, Department of Biological Sciences, North Dakota State University, Fargo.

Gelman, A., Carlin, J.B., Stern, H.S., and Rubin, D.B. 2004. Bayesian data analysis. 2nd edition. Chapman and Hall, New York, and CRC, Boca Raton, Fla.

Gilks, W.R., and Roberts, G.O. 1996. Strategies for improving MCMC. In Markov chain Monte Carlo in practice. Edited by W.R. Gilks, S. Richardson, and D.J. Spiegelhalter. Chapman and Hall, New York. pp. 89-114.

Greenberg, J.D., Logsdon, M.G., and Franklin, J.F. 2002. Introduction to geographic information systems (GIS). In Learning landscape ecology: a practical guide to concepts and techniques. Edited by S.E. Gergel and M.G. Turner. Springer-Verlag, New York. pp. 17-31.

Hammond, M.C., and Johnson, D.H. 1984. Effects of weather on breeding ducks in North Dakota. U.S. Fish Wildl. Serv. Tech. Rep. No. 1.

Hooge, P.N., and Eichenlaub, B. 1997. Animal movement extension to ArcView version 2.0 [online]. Available from http://www. absc.usgs.gov/glba/gistools/animal_mvmt.htm [accessed $15 \mathrm{Au}-$ gust 2005].

Kantrud, H.A. 1989. Vegetation of wetlands of the Prairie Pothole Region. In Northern Prairie wetlands. Edited by A. van der Valk. Iowa State University Press, Ames. pp. 132-187.

Kendall, W.L., Peterjohn, B.G., and Sauer, J.R. 1996. First-time observer effects in the North American breeding bird survey Auk, 113: 823-829.

Krapu, G.L., Klett, A.T., and Jorde, D.G. 1983. The effect of variable spring water conditions on mallard reproduction. Auk, 100: 689-698.

Krapu, G.L., Pietz, P.J., Brandt, D.A., and Cox, R.R., Jr. 2000. Factors limiting mallard brood survival in prairie pothole landscapes. J. Wild1. Manag. 64: 553-561.

Kroodsma, D.E., and Verner, J. 1997. Marsh wren (Cistothorus palustris). In The birds of North America. No. 308. Edited by A. Poole and F. Gill. The Academy of Natural Sciences, Philadelphia, Pa., and the American Ornithologists' Union, Washington, D.C.

Lawson, A.B., Browne, W.J., and Vidal Rodeiro, C.L. 2003. Disease mapping with WinBUGS and MLwiN. John Wiley and Sons, West Sussex, England.

Leitch, J.A. 1989. Politicoeconomic overview of prairie potholes. In Northern Prairie wetlands. Edited by A. van der Valk. Iowa State University Press, Ames. pp. 2-14.

Link, W.A., and Sauer, J.R. 2002. A hierarchical analysis of population change with application to cerulean warblers. Ecology, 83: 2832-2840.

Link, W.A., Cam, E., Nichols, J.D., and Cooch, E.G. 2002. Of BUGS and birds: Markov chain Monte Carlo for hierarchical modeling in wildlife research. J. Wildl. Manag. 66: 277-291.

MacWhirter, R.B., and Bildstein, K.L. 1996. Northern harrier (Circus cyaneus). In The birds of North America No. 210. Edited by A. Poole and F. Gill. The Academy of Natural Sciences, Philadelphia, Pa., and the American Ornithologists' Union, Washington, D.C.

McGarigal, K., Cushman, S.A., Neel, M.C., and Ene, E. 2002. FRAGSTATS: spatial pattern analysis program for categorical maps [online]. Available from http://www.umass.edu/landeco/ research/fragstats/fragstats.html [accessed 6 March 2006].

Miller, M.W. 2000. Modeling annual mallard production in the prairie-parkland region. J. Wildl. Manag. 64: 561-575.

Mitsch, W.J., and Gosselink, J.G. 2000. Wetlands. 3rd ed. John Wiley and Sons, New York.

Muller, M.J., and Storer, R.W. 1999. Pied-billed grebe (Podilymbus podiceps). In The birds of North America. No. 410. Edited by A. Poole and F. Gill. The Academy of Natural Sciences, Philadelphia, Pa., and the American Ornithologists' Union, Washington, D.C.

Murkin, H.R., Murkin, E.J., and Ball, J.P. 1997. Avian habitat selection and prairie wetland dynamics: a 10-year experiment. Ecol. Appl. 7: 1144-1159.

North American Bird Conservation Initiative. 2005. Bird conservation regions [online]. Available from http://Www.nabci-us.org/ bcrs.html [accessed 10 August 2005].

Naugle, D.E., Higgins, K.F., Estey, M.E., Johnson, R.R., and Nusser, S.M. 2000. Local and landscape-level factors influencing black tern habitat suitability. J. Wildl. Manag. 64: 253-260.

Naugle, D.E., Johnson, R., Estey, M.E., and Higgins, K.F. 2001. A landscape approach to conserving wetland bird habitat in the Prairie Pothole Region of eastern South Dakota. Wetlands, 21: 117. doi:10.1672/0277-5212(2001)021[0001:ALATCW]2.0.CO;2.

Newbold, S., and Eadie, J.M. 2004. Using species-habitat models to target conservation: a case study with breeding mallards. Ecol. Appl. 14: 1384-1393.

Peer, B.D., and Bollinger, E.K. 1997. Common grackle (Quiscalus quiscula). In The birds of North America. No. 271. Edited by A. Poole and F. Gill. The Academy of Natural Sciences, Philadelphia, Pa., and the American Ornithologists' Union, Washington, D.C.

Pribil, S., and Picman, J. 1997. The importance of using the proper 
methodology and spatial scale in the study of habitat selection by birds. Can. J. Zool. 75: 1835-1844.

R Development Core Team. 2005. R: A language and environment for statistical computing. R Foundation for Statistical Computing, Vienna, Austria. Available from http://www.R-project.org [accessed 28 March 2006].

Root, T. 1988. Energy constraints on avian distributions and abundances. Ecology, 69: 330-339. doi:10.2307/1940431.

Rohwer, F.C., Johnson, W.P., and Loos, E.R. 2002. Blue-winged teal (Anas discors). In The birds of North America. No. 625. Edited by A. Poole and F. Gill. The Academy of Natural Sciences, Philadelphia, Pa., and the American Ornithologists' Union, Washington, D.C.

Saab, V. 1999. Importance of spatial scale to habitat use by breeding birds in riparian forests: a hierarchical analysis. Ecol. Appl. 9: $135-141$.

Sauer, J.R., Peterjohn, B.G., and Link, W.A. 1994. Observer differences in the North American breeding bird survey. Auk, 111: $50-62$.

Sauer, J.R., Fallon, J.E., and Johnson, R. 2003. Use of North American breeding bird survey data to estimate population change for bird conservation regions. J. Wildl. Manag. 67: 372-389.

Sauer, J.R., Hines, J.E., and Fallon, J. 2005. The North American breeding bird survey, results and analysis 1966-2005. Version 2005.2. USGS Patuxent Wildlife Research Center, Laurel, Md.

Spiegelhalter, D.J., Best, N.G., Carlin, B.P., and van der Linde, A. 2002. Bayesian measures of model complexity and fit. J. R. Stat. Soc. B Met. 64: 583-639.

Spiegelhalter, D.J., Thomas, A., and Best, N.G. 2003. WinBUGS version 1.4 user manual. MRC Biostatistics Unit, Cambridge, UK. Available from http://www.mre-bsu.cam.ac.uk/bugs/ winbugs/manual 14.pdf [accessed 1 June 2005].

Thogmartin, W.E., Gallant, A.L., Knutson, M.G., Fox, T.J., and Suárez, M.J. 2004a. A cautionary tale regarding use of the national land cover dataset 1992. Wildl. Soc. Bull. 32: 970-978.

Thogmartin, W.E., Sauer, J.R., and Knutson, M.G. 2004b. A hier- archical spatial model of avian abundance with application to cerulean warblers. Ecol. Appl. 14: 1766-1779.

Thogmartin, W.E., Knutson, M.G., and Sauer, J.R. 2006. Predicting regional abundance of rare grassland birds with a hierarchical spatial count model. Condor, 108: 25-46. doi:10.1650/00105422(2006)108[0025:PRAORG]2.0.CO;2.

Twedt, D.J., and Crawford, R.D. 1995. Yellow-headed blackbird (Xanthocephalus xanthocephalus). In The birds of North America. No. 192. Edited by A. Poole and F. Gill. The Academy of Natural Sciences, Philadelphia, Pa., and the American Ornithologists' Union, Washington, D.C.

Urban, D.L. 2005. Modeling ecological processes across scales. Ecology, 86: 1996-2006.

Venier, L.A., McKenney, D.W., Wang, Y., and McKee, J. 1999. Models of large-scale breeding-bird distribution as a function of macro-climate in Ontario, Canada. J. Biogeogr. 26: 315-328. doi:10.1046/j.1365-2699.1999.00273.x.

Venier, L.A., Pearce, J., McKee, J.E., McKenney, D.W., and Niemi, G.J. 2004. Climate and satellite-derived landcover for predicting breeding bird distribution in the Great Lakes basin. J. Biogeogr. 31: 315-331.

Vierling, K.T. 1999. Habitat quality, population density, and habitat-specific productivity of red-winged blackbirds (Agelaius phoeniceus) in Boulder County, Colorado. Am. Midl. Nat. 142: 401-409. doi:10.1674/0003-0031(1999) 142[0401:HQPDAH]2.0. $\mathrm{CO} ; 2$.

Yasukawa, K., and Searcy, W.A. 1995. Red-winged blackbird (Agelaius phoeniceus). In The birds of North America No. 184. Edited by A. Poole and F. Gill. The Academy of Natural Sciences, Philadelphia, Pa., and the American Ornithologists' Union, Washington, D.C.

\section{Appendix A}




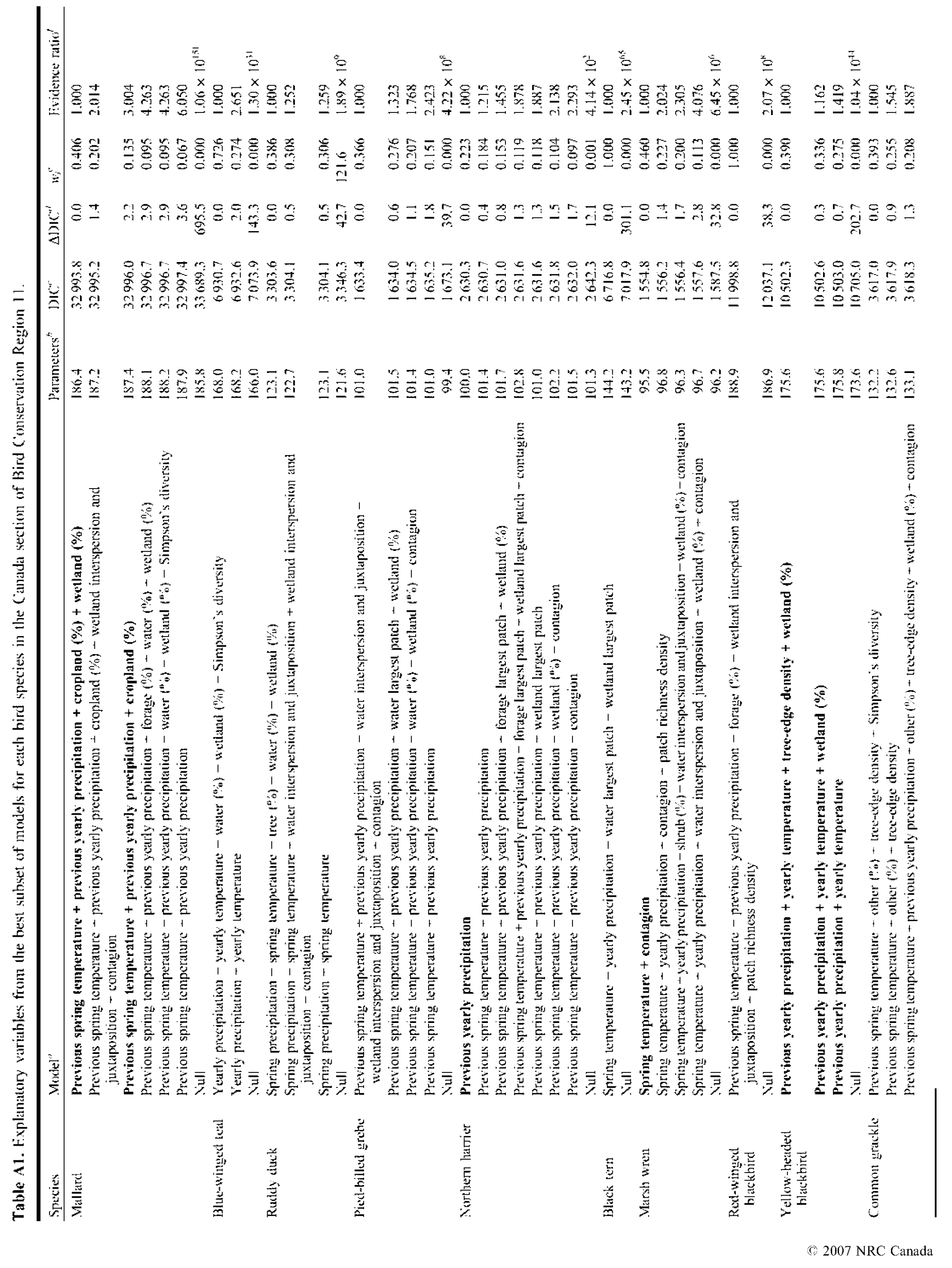




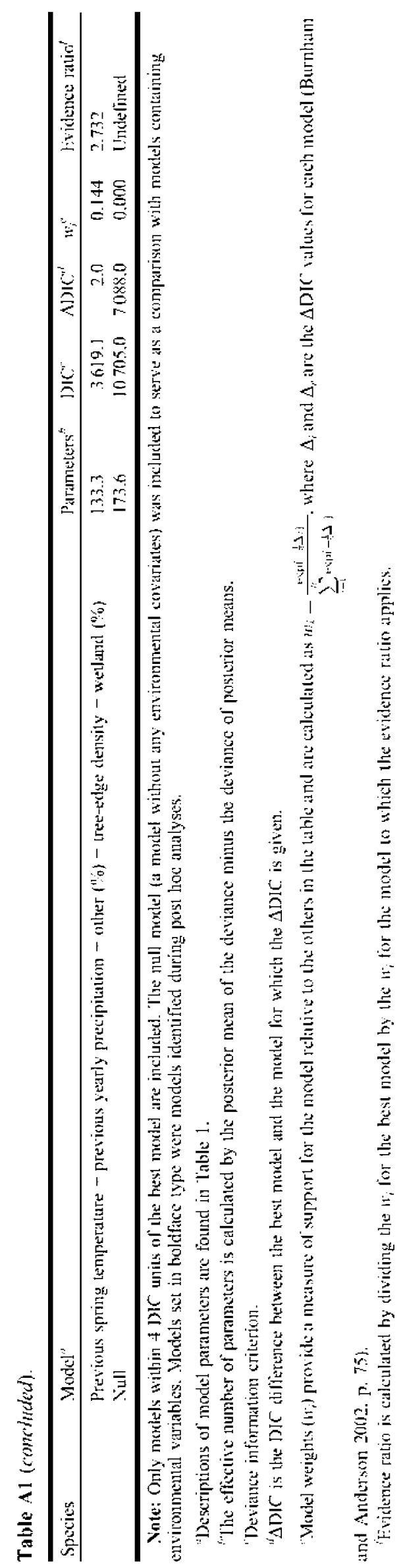

